\title{
Why TTIP is an unprecedented geopolitical game-changer, but not a Polanyian moment
}

Leif Johan Eliasson, East Stroudsburg University (jeliasson@esu.edu)

Patricia Garcia-Duran, University of Barcelona (patriciagarciaduran@ub.edu)

\section{Abstract $^{1}$}

This paper looks at the TTIP from a trade policy perspective. It argues that while TTIP is an unprecedented bilateral agreement, it does not constitute a Polanyian moment. TTIP is unprecedented in both EU and international trade policy terms because it offers an alternative to WTO multilateralism. Never before has bilateralism offered such a 'best alternative to no agreement' (BATNA) to members of the core decision-making body of the WTO negotiating arm, making TTIP an unprecedented geopolitical game-changer. The anti-TTIP campaign, however, has not been driven either by geopolitical or trade liberalization concerns but by fears about EU bargaining power. By strategically focusing on the potential impact on public policy and safety standards, normative arguments promulgated by opponents to TTIP reflect concerns with perceived threats to the EU status quo, and a willingness to preserve the same. The US is presented (implicitly) as more powerful than the EU, and therefore perceived as able to impose its preferences which are considered too neo-liberal.

\section{Introduction}

When TTIP negotiations commenced in 2013 proponents' main arguments centered on the agreement's potential economic benefits. Removing most or all tariffs and (up to) half of nontariff barriers would increase trade and investments, spur growth, and create jobs (Felbermayr, 2013; François, 2013). The economic benefits of a TTIP for both Europe and the US far exceed those resulting from a potential completion of the Doha Round, and are worth five times the EU-South Korean deal (cf.eg. Erixon and Bauer 2010). Economic gains notwithstanding, the debate has come to focus predominantly on standards and geopolitical gains, with advocates arguing that TTIP would go further than any previous agreement; setting high global standards in most sectors, while solidifying the rules-based international system erected primarily by the transatlantic partners after WWII. Opponents tend to disagree, arguing TTIP may threaten public health, safety, and services.

This paper first looks at how TTIP's (potential) geopolitical impact makes it unique in international and EU trade policy. We examine how TTIP is unprecedented because it implies creating an alternative to multilateralism through the World Trade Organization (WTO) and that in turn reflects a shift in EU trade policy bilateral approach. In fact, never before has bilateralism offered such an appealing 'best alternative to no agreement' (BATNA) in the WTO. By so doing, we complement De Bièvre \& Poletti's public goods approach (this debate-section) on the international implications of TTIP, while challenging their conclusion that this agreement is not (so) unique. 
In the second half of the paper we turn to opponents' arguments. Opponents have continuously asserted that TTIP threaten Europeans' health and safety. Premised on the assumption that American standards are lower and that an agreement including mutual recognition or convergence of regulations will allow American products with lower standards into the EU, they foresee a 'race to the bottom' on standards (cf. e.g. De Ville and Siles-Brügge, 2016). They also claim that business will gain the upper hand in public policy through the inclusion of a corporate-biased investment arbitration system (BEUC, 2014; Friends of the Earth, 2016). These arguments have provoked unprecedented and vocal public opposition, and De Ville \& Siles-Brügge (this debate-section) argue that TTIP may well represent in Polanyian terms a societal move against market "disembedding" (what we refer to from now on as a Polanyian moment). By looking at the underlying assumptions of these claims, we instead argue that TTIP concerns are driven by fears about the EU's bargaining power vis-à-vis the US.

\section{Why TTIP is an unprecedented geopolitical game-changer}

The US and its European allies erected and then controlled the governance of the international trade system for several decades after WWII. Despite concessions to developing countries, consensus building in both the GATT and the WTO up until 2003 depended on agreement in the so-called Quad (the US, the EC/EU, Japan and Canada). After the WTO ministerial meeting in Cancún in 2003, two emerging markets (India and Brazil) replaced two developed countries (Japan and Canada) in the Quad, with three other members occasionally joining to form groups like the G5 (with Australia), G6 (which adds Japan) or G7 (which adds China). Thus, while the transatlantic partners remain the key players in the new nucleus of power in the multilateral trade system, they now have to address concerns from countries opposed to the dominance of the EU and the US - countries with often very different preferences - if hoping to complete a multilateral agreement. ${ }^{2}$

As this power realignment within the WTO failed to enable a completion of the Doha Round in 2008 , leading to stalemate in multilateral negotiations and raising doubts whether the WTO could serve its core mission of trade liberalization, TTIP could be what Steinberg (2002:349) calls an 'exit tactic'. In short, the potential for Old Quad partners establishing a preferential market through bilateral agreements (i.e., threating isolation) would lead the new de facto trade veto players in the WTO to lower their expectations and facilitate a WTO multilateral (or at least plurilateral) compromise. There is some tentative evidence to this effect. Since the TTIP negotiations were launched, some mini-package agreements have been possible in the WTO Ministerial Meetings both of December 2013 in Bali and December 2015 in Nairobi, arguably to prevent the WTO negotiating arm from becoming irrelevant (Falconer, 2015; Hamilton, 2014). 
However, serving as a response to problems with multilateral negotiations, this time the Doha Round, would not make TTIP an unprecedented bilateral agreement. The existence of a nexus between the multilateral context and other bilateral agreements has been underlined by several authors. Bergsten and Schott (1997: 3), in their preliminary evaluation of NAFTA, argue that 'The startup of NAFTA negotiations in 1991 gave renewed impetus to the Uruguay Round in the GATT, which had stalled in 1990 because of US-Europe differences over agriculture, by reminding the Europeans that the United States could pursue alternative trade strategies.' Mansfield and Reinhardt (2003: 829) find that 'developments at the heart of GATT/WTO encourage its members to form PTAs [preferential trade agreements] as devices to obtain bargaining leverage within the multilateral regime'. Their conclusion has been vindicated in a more recent quantitative analysis where Baccini and Dür (2012) find that 'countries are more likely to sign an agreement in tandem with negotiations at the WTO level' ( $p$ 75).

What makes TTIP an unprecedented geopolitical game-changer is that even if it fails to foster an agreement at the multilateral level ('exit tactic' fails), TTIP still offers the EU and the US the possibility of establishing global rules. The size of the transatlantic market ( $50 \%$ of global FDI and $40 \%$ of global trade, and the EU remains the US' largest market even after the UK leaves), the scope of TTIP (especially regulatory cooperation and convergence, investment rules, and standard setting across several other sectors, including autos; see De Ville \& Siles-Brügge, this debate section), and the development of trade through supply-chains give the EU-US tandem an unprecedented capacity for regulatory export. Never before had bilateralism offered such an appealing BATNA to key players in the WTO. ${ }^{3}$

The benefits of rules convergence and regulatory equivalence are pronounced in helping companies better integrate in the supply-chain trade. Baldwin and Lopez-Gonzalez (2015) show that international supply chains are both global and regional in nature, structured around three regional supply networks or factories (Factory Asia, Factory Europe and Factory North-America), where the US, Germany, Japan, and China dominate supply-chain trade globally. In such a context, an agreement between two of the regions (factories) - i.e., the exclusion of at least an important part of one if taking account of the Trans-Pacific Partnership (TPP) and negotiations for a bilateral trade agreement between Japan and the EU - may consolidate vital global value chains and therefore affect the regulatory strategies of companies in both signature states and third countries, while an agreement on either technical standards or rules (investment, public procurement, competition policy, environment or labor) also spurs third country exporters' adaptation to the integrated zone (here TTIP). In a context of supply-chains emerging countries' exporters (read especially China) will have to comply with standards to access the transatlantic market place; additionally, TTIP member firms exporting parts and components to emerging markets constitute a second level of external pressure on public authorities to adopt those standards (Layne, 2014; Guoyou and Wen, 2012). 
De Bièvre \& Poletti (this debate-section) explain how and why third countries are expected to react by adaptation rather than confrontation to TTIP standards and rules. Our main interest here is to underline that the potential to establish global standards and rules (even if their spread will not be uniform across space and time) makes TTIP a case of what Morse and Keohane (2014) call 'contested multilateralism' (or 'counter-multilateralism')'. More specifically, TTIP takes the form of 'competitive regime creation'(Ibid), where two powerful actors, the US and the EU, challenge the institutional (WTO) status quo, dissatisfied with its progress by creating a new institution. Hence, the objective is not to substitute multilateralism with bilateralism but rather to create an alternative to established multilateralism. It is the first time that the WTO faces such a challenge.

The fact that TTIP represents a challenge to the established international trade regime (WTO) also makes it an unprecedented agreement from an EU trade policy perspective. At first sight, TTIP does not look unique. As other bilateral agreements the EU is negotiating with developed countries, it evidences the two successive changes EU's trade policy bilateral approach has undergone in the $21^{\text {st }}$ century: a shift towards commercial aims and a shift towards safeguarding EU position in the international trade order. Regarding the first, in 2006 the Commission officially abandoned its self-imposed moratorium (since 1999) on new preferential trade agreements. While political and security interests were traditionally pursued through bilateral and/or regional agreements, the bilateral approach would now also serve economic interests, initially focusing on major emerging economies. As the European Commission put it in Global Europe (2006:10-11),'FTAs are by no means new for Europe. ...But while our current bilateral agreements support our neighbourhood and development objectives well, our main trade interests, including in Asia, are less well served. ...economic factors must play a primary role in the choice of future FTAs'. The second shift was captured in Commission's 2010 communiqué (Trade, Growth and World Affairs) and reinforced in the EU's new (2015a) trade policy strategy, Trade for All. Both documents advocate focusing on bilateral agreements with non-European developed countries, that is, with the members of the old trade 'club' that had controlled the governance of the trade multilateral system up until Cancún (see Keohane and Nye, 2001 on the post-WWII 'club model'). On the other hand, however, TTIP is different from the other bilateral agreements the EU is negotiating with developed countries because it is the only one to offer a BATNA vis-à-vis a multilateral agreement.

To sum up, what makes the TTIP an unprecedented bilateral agreement both in international and EU trade policy terms is its capacity to substitute for WTO standards and rules setting arm. TTIP offers its partners (EU-US) the possibility to continue setting global standards without the need to reach agreement with other key trade players at the WTO. That capacity however relies on the partners being able to reach an ambitious agreement on non-tariffs issues, which in turn implies a sharing of sovereignty that, as we argue in the next section, is being hampered by fears regarding the EU's bargaining power. 


\section{Why TTIP does not constitute a Polanyian moment}

Its many benefits notwithstanding, TTIP negotiations have faced unprecedented and increasingly vocal public opposition, generated by European civil society groups (CSO). De Ville \& Siles-Brügge (in this section) argue that TTIP is a Polanyian-moment because the debate centers on a trade-off between EU values and trade liberalization. Here we challenge their conclusion. Rather than apprehension towards trade liberalization TTIP opposition is driven by concerns with the EU's bargaining power and fears that the US will impose its neo-liberal market-oriented model. If the EU was perceived as stronger than the US, TTIP would not be contested (or at least to a much lesser extent).

Our argument is based on both empirics and a counterfactual. As to the first, Eurobarometer surveys show EU wide support for TTIP shrunk from $59 \%$ to 52\% between April 2014 and November 2015, but German support plummeted, from 55\% to $17 \%$ by April 2016; another trade-dependent member, Austria exhibited a similar decline. Yet there is no correlation between opinions on trade in general across the EU (which remains stable at 65-88\%) and views on TTIP. ${ }^{5}$ Furthermore, while a plurality of Germans admit not knowing enough about TTIP to form an opinion (meaning they can be swayed), Germans strongly support free trade and never previously expressed fears that an agreement would impose a partner's standards, yet that is exactly what those opposing TTIP fear (Bertelsmann, 2016; Emnid, 2015; Pew, 2014).

As to the counterfactual: if TTIP was a Polanyian moment, we would expect a 'new threshold had been crossed in the balance between "market" and "authority", with governments assuming much more direct responsibility for domestic social security and economic stability' (Ruggie,1982: 388). In other words, it would imply a shift from less government involvement to more direct control over market forces. Yet, upon inspection one finds that opponents are not demanding increased 'authority' over the 'market' in their main issues of contention: the investment arbitration system and EU standards. On the first, opponents are instead afraid of governments losing 'authority' to the 'market'. On the second, the problem is not the balance between 'authority' and the 'market' but the balance between 'authorities'.

If opponents would have wanted increased 'authority' over the 'market' on investors rights, they should welcome reforms which curtail corporate access to legal redress vis-à-vis governments, like those proposed by the European Commission. EU Member States are signatories to over 1,400 Bilateral Investment Treaties (BITs, of which 200 are intra EU, cf. European Commission, 2015b), containing vaguely worded language on when and how a foreign investor may sue the state for violating the terms of its investment agreement, a general system called Investor-State Dispute Settlement (ISDS). In September 2015, in response to public outcry, the Commission presented a highly reformed, narrowly defined, and 
precedent setting arbitration system (now called Investment Court System) for inclusion in TTIP (a modified version was adopted in CETA).

While some would advocate further changes, there is consensus that the proposed reforms include an increase of 'authority' over the process: explicit public policy safeguards, narrow definition of terminology, allowance for external submissions, transparency in filings, prohibition on dual track pursuits, empowerment of arbitrators to dismiss unwarranted cases, bans on tobacco company claims, and 'loser pays legal expenses' provisions (Commission, 2015c). Most opponents, however, remain unconvinced, persisting in their argument that any investment arbitration system inclusion in TTIP would lead to 'regulatory chill' (where governments lose 'authority' to the 'market', e.g. Friends of the Earth, 2016). When asked specifically why the status quo would be preferable to reforms the responses from a leading EU-wide CSO and a labor union organization were, respectively, 'the other agreements were not our focus, not our priority...[now] our strategy is to stop ISDS in TTIP and CETA first, then go after the BITs over time', and tellingly, 'we have no strategy, we don't know'. ${ }^{6}$ The underlying problem therefore does not seem to be the arbitration system per se but rather the partner.

Another arrow pointing in this direction is the timing of the protests. If opponents were solely worried about the investment arbitration system's inadequacies, they would have already protested against pre-existing BITs. Objections arising after 55 years of practice and with ISDS included in other recent agreements, point to the real problem being the US; a point dismissed in public but acknowledged in private by two of the largest pan-European organizations. ${ }^{7}$ De Ville \& Siles-Brügge (in this section) reference a CSO report that TTIP would be more difficult to terminate than existing bilateral BITs, partly because more investment is affected. Yet if the principle objection is to the unfair nature of the arbitration system even a single treaty with ISDS should be objectionable, and there were no protests or public mobilization prior to TTIP's launch.

Further convoluting opponents' argument is the acknowledgment by groups such as BEUC that European firms need investment protection in certain countries with politicized and corrupt courts (read China, Brazil, and India). However, not only would this entail a politicization of when and where ISDS is appropriate (imagine attempting agreement on what constitutes 'a mature and independent legal system'), not all European and American courts are paragons of legal virtue. The US State Department's 2015 Investment Climate Statements reveal concerns about investor protection in Romania and Bulgaria, and several European business representatives and policy experts express doubts about many American states' courts adherence to international agreements and treatments of foreign investors (SIIA, 2014). ${ }^{8}$ Existing EU members also do not wish to give up their own intra-EU BITs with judicially weaker members (e.g. Romania, Bulgaria) without a replacement, as exemplified by Italy erecting six special investor courts after cancelling its intra-EU BITs in 2013, and five Member States 
(including Germany and Austria) proposing a 'Super-ISDS' to replace existing agreements (Council, 2016).

Identifying the real problem as the partner rather than trade liberalization can also be inferred from the opponents' fears regarding EU standards which anti-TTIP groups contend will either be lowered by having to adapt to American ones (by accepting American standards as equivalent, thus indirectly lowering European standards), or prevented from being strengthened because of 'regulatory chill' from the horizontal regulatory commitments through a regulatory cooperation body (De Ville and Siles-Brügge, 2016). In other words, opponents doubt America's level of consumer protection as well as the EU's ability to stand up to US demands and to share 'authority' with the US (on asymmetric bargaining power, see Conceiçao-Heldt, 2014).

CSOs' prolific criticisms of American standards as 'weak' and 'less safe' have been effectively distributed through position papers, social media campaigns ( $90 \%$ of German social media posts on TTIP were negative, see Bauer, 2015; and twitter is dominated by anti-TTIP posts, see Ciofu and Stefanuta, 2016), protests, and public statements, often picked up by the mainstream media. Many opponents also point to leaked negotiating texts (proposals) they interpret as showing the Commission's willingness to accommodate American demands on key issues (e.g. Greenpeace, 2016) - claims sternly rejected by the Commission.

Yet, even if accepting that some US standards may be lower in certain areas, this should not, in reality, be a problem. The EU can refuse to accept certain US standards as equivalent to those in the EU, what Young (2015: 1241) calls the power of 'exclusion'. Indeed, why would the EU offer a blank acceptance of US standards? Where is the precedent? The EU has already negotiated several comprehensive agreements with third countries with lower standards (at least in certain issues) without raising fears of a weakening of EU standards because nobody expects the automatic acceptance of those countries' products. Even within the European Single Market mutual recognition does not always allow a product legally sold in one member to be sold in another; exceptions for health and safety ensure that some member states rules regarding a product or service are deemed non-equivalent by other Member States (European Commission, 2012:83, 2015d). To sustain their argument that TTIP will lower safety standards, opponents are thus assuming that the US will be able to impose its preferences even as this would entail the EU abandoning previous practices in trade negotiations and within its own single market.

The problem is thus not the market system but rather the choice of partner; the US is presented (implicitly) as more powerful than the EU, and therefore perceived as able to impose its preferences. Opponents are not demanding an increase of 'authority' over the 'market'. Rather, their preference is to preserve the status quo of fears that negotiations with 
the US will lead to EU member states losing control over domestic policies and EU standards. Public opposition to TTIP reflects such concerns with perceived threats to the European status quo, fueled by beliefs that the EU cannot stand up to American demands and that the US model is too liberal. In other words, opposition to TTIP is premised on a desire to preserve the EU's internal equilibrium between free market forces and welfare economy (a sui-generis model of 'embedded liberalism'), ${ }^{9}$ rather than a desire to change it.

\section{Conclusion}

TTIP supporters' focus on geopolitical gains, global standard and rule setting, as well as classic economic benefits of trade liberalization, reflect this agreement's unprecedented nature from both an international and EU trade policy perspective. While other (past or present) bilateral agreements may also to varying degree stem from difficulties at multilateral negotiations, only TTIP qualifies on its own as a new means of setting global norms (a fact that may also help ensure its success as an 'exit tactic'). Bièvre \& Poletti's assertion (this debate section) that TTIP is not (so) unique should therefore be qualified.

Opponents focus on TTIP's potential impact on public policy and safety standards, reflecting their concerns with perceived threats to the EU status quo, and a willingness to preserve the same. By deliberately choosing specific issues to evoke the greatest fears they have garnered unexpected and unprecedented public opposition to a trade agreement (Eliasson, 2016). Thus, rather than a larger debate on whether the market will become too liberalized (Polanyian moment) under modern trade agreements as De Ville \& Siles-Brügge argue (this debate section), opponents' evocation of fears, of 'wild-west' neo-liberalism and 'lower standards' through TTIP reveal many Europeans' self-doubt of the ability to negotiate as an equal with the US (power-politics).

\section{Notes}

\section{References}

Baccini, L. and A. Dür (2012) 'The New Regionalism and Policy Interdependence', The British Journal of Political Science 42 (1):57-71

Baldwin, R. and Lopez-Gonzalez, J. (2015) 'Supply-chain Trade: A Portrait of Global Patterns and Several Testable Hypotheses', The World Economy 38(11): 1682-1721.

Bergsten, C. F. and Schott, J. J. (1997) 'A Preliminary Evaluation of NAFTA', Testimony before the Subcommittee on Trade Ways and Means Committee of the United States House of Representatives, Washington, DC, September 11. 
Bertelsmann Foundation (2016) 'Attitudes to global trade and TTIP in Germany and the United States' at https://www.bertelsmann-

stiftung.de/fileadmin/files/BSt/Publikationen/GrauePublikationen/NW Attitudes global trade and TTIP.pdf (accessed 7 July, 2016)

Bauer, M. (2015) 'Groups Dominate German Online Media and Set the Tone for TTIP Opinion', ECIPE blog, at http://www.ecipe.org/blog/anti-ttip-german-online-media/ (accessed 3 January 2016)

European Consumer Organization (BEUC) (2014) The Micula case: When ISDS messes with EU law, 27 October, 2014, http://www.beuc.eu/blog/the-micula-case-when-isds-messes-with-eulaw/ (accessed 3 December 2015)

European Consumer Organization (BEUC) (2014), Consumers at the heart of the Transatlantic Trade and Investment Partnership, Position Paper, 21 May, http://www.beuc.eu/publications/beuc-x-2014-031 mgo ttip updated.pdf (accessed 7 February 2016)

Cernat, L. (2013) 'TPP, TTIP and multilateralism: stepping stones or oceans apart?' Voeux, November 8, at http://voxeu.org/article/bilateral-renaissance-or-multilateralism (accessed 5 March 2016)

Ciofu, Sabina Maria and Nicolae Stefanuta, Nicolae (2016) TTIP, the Bullied Kid of Twitter. Geoprgetown Public Policy Review, January, at

http://gppreview.com/2016/01/14/ttip-twitter-and-how-social-media-is-defining-the-publicargument/ (accessed 8 February 2016)

Conceiçao-Heldt, E. da (2014) 'When speaking with a single voice isn't enough: bargaining power (a)symmetry and EU external effectiveness in global trade governance', Journal of European Public Policy 21(7): 980-995.

Council of the European Union (2016) 'Intra-EU Investment Treaties Non-paper from Austria, Finland, France, Germany and the Netherlands' Trade Policy Committee, 7 April.

De Ville, F. and Siles-Brügge, G. (2016) The Truth about the Transatlantic Trade and Investment Partnership, Cambridge, UK: Polity Press.

Leif Johan Eliasson (2016) 'The Transatlantic Trade and Investment Partnership: Interest Groups, Public Opinion, and Policy' in Different Glances at EU Trade Policy (Barcelona: Barcelona Center for International Affairs)

Emnid. (2015) 'Emnid-Umfrage: Zustimmung zu TTIP stagniert auf Allzeit-Tief TTIP-Kritiker in der SPD können die Mehrheit der Bevölkerung hinter sich wissen', at, https://blog.campact.de/wp-content/uploads/2015/12/Umfrage-TTIP-Dez-20151.pdf (accessed 22 August 2016)

Erixon, F and Bauer, M. (2010) 'A Transatlantic Agreement: Estimating the Gains from Transatlantic Free Trade in Goods', Brussels: ECIPE Occasional Paper 4. 
European Commission (2006) Global Europe-Competing in the World, at http://trade.ec.europa.eu/doclib/docs/2006/october/tradoc 130376.pdf (accessed 22 August 2016)

European Commission (2010) Trade, Growth, and World Affairs, Trade Policy as a Component of the 2020 Strategy. At

http://trade.ec.europa.eu/doclib/docs/2010/november/tradoc 146955.pdf (accessed 22 August 2016)

European Commission (2012) Evaluation of the Application of the mutual recognition principle in the field of goods, ENTR/172/PP/2012/FC - Lot 4

European Commission (2015a) Trade for All- Towards a More Responsible Trade and Investment Policy. At http://trade.ec.europa.eu/doclib/docs/2015/october/tradoc 153846.pdf (accessed 22 August 2016)

European Commission (2015b) Commission asks Member States to terminate their intra-EU bilateral investment treaties. Brussels, 18 June 2015, at

http://europa.eu/rapid/press-release IP-15-5198 en.htm (accessed 22 August 2016)

European Commission (2015c) Transatlantic Trade and Investment Partnership Trade in Services, investment, and E-Commerce Chapter II- Investment, at

http://trade.ec.europa.eu/doclib/docs/2015/november/tradoc 153955.pdf (accessed January 30, 2016)

European Commission (2015d) A Single Market Strategy for Europe -Analysis and Evidence, Commission Staff Working Document SWD (2015)202final.

Falconer, Crawford (2015) "From Nairobi to Confidence Building in Geneva", Policy brief, International Centre for Trade and Sustainable Development, Geneva, Switzerland.

Friends of the Earth Europe (2016) 'Investment Court System put to the test: new EU proposal will perpetuate investors' attacks on health and environmentat', 19 April, at http://www.foeeurope.org/investment-court-system-put-to-test (accessed 7 July, 2016)

Felbermayr, G. et al. (2013) Transatlantic Trade and Investment Partnership (TTIP): Who benefits from a free trade deal? Global Economic Dynamics Paper, Gütersloh: Bertelsmann Stiftung.

François, J. et al (2013) 'Reducing Transatlantic Barriers to Trade and Investment - An

Economic Assessment', Final Report for the European Commission, Contract TRADE10/A2/A16, Center for Economic Policy Research, London.

Greenpeace (2016) multiple documents, at https://www.ttip-leaks.org/ (accessed 8 July, 2016)

Guoyou S. and Wen, J. Y. (2012) 'China's Free Trade Agreement Strategies', Center for Strategic and International Studies. The Washington Quarterly, 35 (4): 107-119 
Hamilton, D. (ed) (2014) The Geopolitics of TTIP; Repositioning the Transatlantic Relationship for a Changing World, Center for Transatlantic Relations, John Hopkins University

Keohane R.O. and Nye Jr., J. S. (2001) 'Between Centralization and Fragmentation: The Club Model of Multilateral Cooperation and Problems of Democratic Legitimacy' Kennedy School of Government Faculty Research Working Paper Series RWP01-004, 1-25.

Lamy, P. (2015) 'The New Global Trade Agenda', Peterson Institute for International Economics, Washington Dc, Unedited Event Transcript.

Layne, C. (2014) After the Fall, International Politics, U.S. Grand Strategy, and the End of the Pax Americana. New Haven: Yale University Press.

Mansfield, E. D. and Reinhardt, E. (2003) 'Multilateral determinants of Regionalism: The Effects of GATT/WTO on the Formation of Preferential Trading Arrangements', International Organization 57(4), 829-862.

Morin, J.F. et al (2015) The Politics of Transatlantic Trade Negotiations: TTIP in a Globalized World, Farnham, Ashgate.

Morse, J. C. and Keohane, R.O. (2014) 'Contested multilateralism', Review of International Organization 9, 385-412.

Pew (2014). Support in Principle for U.S.-EU Trade Pact, But Some Americans and Germans Wary of TTIP Details. Washington DC: Pew Research Center's Global Attitudes Project, http://www.pewglobal.org/2014/04/09/support-in-principle-for-u-s-eu-trade-pact/ (accessed 12 June 2014)

Ruggie, J. G. (1982) 'International Regimes, Transactions, and Change: Embedded Liberalism in Postwar Economic Order', International Organization 36(2): 379-415.

Steinberg, R. H. (2002) 'In the Shadow of Law or Power? Consensus-Based Bargaining and Outcomes in the GATT/WTO', International Organization 56(2): 339-374.

SIIA-Swedish Institute for International Affairs (2014) The Transatlantic Trade and Investment Partnership (TTIP) - Challenges and Opportunities Ahead, Seminar, 13 October.

Tellis, A. (2015) 'The geopolitics of the TTIP and the TPP' Adelphi Series 54 (450): 93-120.

Young, A.R. (2015) 'The European Union as a global regulator? Context and comparison', Journal of European Public Policy 22 (9): 1233-1252.

Zangl, B. Et al. (2016) 'Imperfect Adaptation: How the WTO and the IMF Adjust to Shifting Power Distributions among their Members', Paper presented at the 2016 Barcelona Workshop on Global Governance, 4-5 February. Forthcoming in Review of International Organizations. 


\footnotetext{
${ }^{1}$ We thank the other contributors to this debate section, the attendees at the EUIA2016 conference and two anonymous referees for their valuable comments. The research for this article was supported by the Catalan Research Council (AGAUR 2014 SGR 704) and the Charles Koch Foundation.

${ }^{2}$ There has not been a full-blown 'power transition', where one hegemon is replaced by another, but rather a 'power shift' characterized by the relative rise of newly emerging power centers (such as China, India or Brazil) and the concomitant (relative) decline of established ones (the US and the EU) (Zangl et al, 2016: 3).
}

${ }^{3}$ Even the Trans-Pacific Partnership, another mega-regional that includes the US and Japan, is not considered to offer such a BATNA either in economic or normative terms (Lamy, 2015; Cernat, 2013)

${ }^{4}$ Keohane and Morse used the term "counter-multilateralism" instead of "contested multilateralism" in a shortened version of their 2014 article published as a chapter in Morin et al. (2015).

${ }^{5}$ Correlation coefficient 0.006 (in seven member states, authors' calculations using 2015 Eurobarometer data).

${ }^{6}$ Interviews, Brussels, March and May 2016.

${ }^{7}$ Interviews, Brussels, March and May, 2016

${ }^{8}$ Also confirmed in interviews with Commission officials and TABC members, October 2014 and February 2015.

${ }^{9}$ Following Ruggie (1982: 399), "embedded liberalism" is "a form of multilateralism that is compatible with domestic stability". 